\title{
THE SCHOOL CURRICULUM: A CULTURAL HISTORY VIEWPOINT AND THE MODERNIZATION OF THE ARITHMETICS TEACHING IN PARANÁ'S STATE PRIMARY SCHOOLS IN THE EARLY XX ${ }^{\text {TH }}$ CENTURY
}

\author{
Neuza Bertoni Pinto ${ }^{1}$
}

\begin{abstract}
From the viewpoint of cultural history, this paper analyzes disputes about purposes and methods for teaching arithmetic's in Paranás state primary schools, as published in the magazine A Escola (The School) in the early XXth century. It highlights behind-the-scenes speeches by intellectuals who advocated a laic and free primary education, in which the main issue, besides of the pedagogical order, was also social and political, an aspect generally absent in the curriculum guidelines.
\end{abstract}

Keywords: curriculum history, cultural history, history of school disciplines, arithmetic purposes, arithmetic teaching method.

${ }^{1}$ Universidade Federal de Mato Grosso (UFMT), Cuiabá/MT, Brasil. 


\section{O CURRÍCULO ESCOLAR SOB O OLHAR DA HISTÓRIA CULTURAL E A MODERNIZAÇÃO DO ENSINO DA ARITMÉTICA NA ESCOLA PRIMÁRIA PARANAENSE NO INÍCIO DO SÉCULO XX}

\section{RESUMO}

Sob o olhar da história cultural, este artigo analisa disputas sobre finalidades e métodos para ensinar Aritmética nas escolas primárias paranaenses, divulgadas pela revista A Escola, periódico que circulou no estado, no início do século XX. Destaca-se discursos emitidos por intelectuais defensores de um ensino primário laico e gratuito, em que a questão principal, para além da ordem pedagógica, era também de ordem social e política, um aspecto geralmente ausente nas diretrizes curriculares.

Palavras-chave: história do currículo, história cultural, história das disciplinas escolares, finalidades da aritmética, método de ensino da aritmética.

\section{EL CURRÍCULO ESCOLAR DESDE EL PUNTO DE VISTA DE LA HISTORIA CULTURAL Y LA MODERNIZACIÓN DE LA ENSEÑANZA DE ARITMÉTICA EN ESCUELAS PRIMARIAS DEL ESTADO DE PARANÁ A PRINCIPIOS DEL SIGLO XX}

\section{RESUMEN}

Desde el punto de vista de la historia cultural, este artículo analiza las disputas sobre finalidades y métodos para enseñar aritmética en las escuelas primarias del estado de Paraná, publicados por la revista A Escola (La Escuela) a principios del siglo XX. Destaca discursos de intelectuales que abogaban por una educación secular y gratuita, en la que el tema principal, además del orden pedagógico, también era de orden social y política, aspecto a menudo ausente en las directrices curriculares.

Palabras clave: historia curricular, historia cultural, historia de asignaturas escolares, propósitos de aritmética, método de enseñanza de aritmética.

\section{LE CURRICULUM SCOLAIRE DU POINT DE VUE DE L'HISTOIRE CULTURELLE ET DE LA MODERNISATION DE L'ENSEIGNEMENT DES ARITHMÉTIQUES DANS LES ÉCOLES PRIMAIRES DE L'ÉTAT DE PARANÁ AU DÉBUT DU XXe SIÈCLE}

\section{RÉSUMÉ}

Du point de vue de l'histoire culturelle, cet article analyse des disputes sur les fins et les méthodes d'enseignement de l'arithmétique dans les écoles primaires du Paraná, publié par le magazine A Escola (L'école), au début du XXe siècle. Il met en évidence les discours des 
intellectuels qui prônent une éducation laïque et gratuite, dans lequel l'enjeu principal, outre l'ordre pédagogique, était également social et politique, un aspect généralement absent des lignes directrices du curriculum.

Mots-clés: histoire du curriculum, histoire culturelle, histoire des matières scolaires, fins de l'arithmétique, méthode d'enseignement de l'arithmétique. 


\section{INITIAL CONSIDERATIONS ${ }^{2}$}

As a social process every curriculum has a history marked by struggles and conflicts between traditions and naturalized conceptions in society, that is not restricted by laws, regulations, norms and curriculum guides, but also seeks different ways in which subjects appropriate to what is prescribed and legitimized. Conceived in this way, the history of the curriculum does not disregard the complex character of the knowledge comprised therein.

A curriculum history, above all, could not but problematize the knowledge, values and skills that marked an epoch and how such representations were constituted over a period, being of utmost importance for it to be centered on seeking to understand the dynamics that constituted the curriculum as a school artifact. "In this perspective, the curriculum should be seen not only as the expression or representation or reflection of determined social interests, but also as producing certain social identities and subjectivities" (GOODSON, 2012, p. 10).

This understanding of curriculum history has been assumed by numerous scholars, such as Ivor Goodson. He is a researcher of theory and history of curriculum, who has been focusing his attention on internal school processes, in order to try to explain how school subjects, methods and teaching plans have been constituted as mechanisms to differentiate students.

In addition, offering valuable clues to the analysis of the complex relationships between school and society, the school disciplines historian André Chervel proposes that in order to understand historically a school curriculum, it is essential to examine its functioning, its real purposes, and to verify if these are the same found in the legal norms or in the prescribed curriculum, since the purposes are expressed only in disciplinary practices, meaning, in the

\footnotetext{
2 This study, with countless alterations, was previously presented, with the title "A history of the curriculum under the viewpoint of the history of school subjects", in a Round Table of the XIV Paranaense Meeting of Mathematical Education - XIV Eprem, "Diversity and Mathematical Education: challenges and perspectives", promoted by Sbem PR, in September 2017.
} 
curriculum in action.

Such concerns led Chervel to formulate the central question that has guided his theoretical-methodological approach to the history of school disciplines: "why does the school teach as it teaches"? This question is replacing the recurring question that curriculum organizers often pose when they try to innovate it, namely, "what should the school teach?” (CHERVEL, 1990, p. 190).

For the historian, school disciplines are at the center of the curriculum and their function is, at each historical moment, to place instructional content at the service of the educational purpose of the institution. Investigating how the various course disciplines meet the school's intended purpose is a primary aspect of curriculum history.

Corroborating the idea of Goodson and Chervel that the curriculum is not something static, but a social and historical product, therefore, constructed, Viñao (2008), making a retrospective of Goodson's works, concludes:

[...] thus a field of inquiry would be consolidated in the Anglo-Saxon world - that of curriculum history and within it, sometimes identifying with it, the history of school disciplines - notably marked, of course, by Goodson's work, together with other orientations or approaches (VIÑAO, 2008, p. 179).

Recognized as the central core of school culture, the disciplines comprise knowledge and behaviors that are generated within the school.

The school was always conceived as a place of culture, initially, according to an idealized conception of knowledge acquisition and "universal" norms; later, in a critical perspective of ideological inculcation and social reproduction. In either case, little attention has been paid to the internal work of producing a school culture, which is in relation to the set of interacting cultures in a given society, but which contains its own specificities that cannot be addressed solely through the prism of the underdeterminations of the outside world (NÓVOA, 1998, p. 34-35, author highlights). 
To deny the existence of this culture is to not recognize the science of education, the teaching profession and teaching as a scientifically constructed knowledge built with the contributions of education theory. In this perspective, as Chervel (1990) has stated, the school is a creative space and the school disciplines, their genuine spaces for creating different knowledge fields. By highlighting the creative power of the school, the historian deconstructs the image of a passive institution, remembering that the school system not only forms individuals, but also produces a culture (the scholar) that shapes and modifies the culture of global society.

By highlighting the nature of school subjects, Viñao (2008) suggests:

For the study of school subjects I suggest considering them as living organisms. Disciplines are not, in fact, abstract entities with a universal and static essence. They are born and develop, evolve and transform, disappear, swallow, attract and repel each other, stray and unite, compete, relate and exchange information (or borrow it from others) (VIÑAO, 2008, p. 204).

The history of the curriculum is not restricted, therefore, to the history of curriculum thinking, but also to the very history of a school discipline that, according to Julia (2001), requires that the contents should always be studied in relation to their methods and practices.

Julia (2001) states that, despite considerable refinement of the problematization of education history, studies related to school practices that provide visibility to school culture remain unknown. Such studies are described by him as the "set of norms to define knowledge to teach and conducts to inculcate, and a set of practices that allow the transmission of this knowledge and the incorporation of these behaviors" (JULIA, 2001, p. 10). For this historian, this is a difficult task, considering that generally school practices are not recorded. The gap left by the history of such ideas can, according to him, be filled by the history of disciplines. 
Inseparable from its educational purposes, as stated by Chervel (1990), the school may not be reduced to programmatic teaching, considering the freedom of teachers to invent procedures in the face of the commitment of bringing a pedagogical renewal to a group of students.

To consider the school curriculum from the cultural history perspective provides an insight about the dynamism of school culture, requires the visiting of official documents of a particular historical period and examining how such codes, regulations and programs worked in the school, i.e., how school agents, teachers and students appropriated of that in their school work. For this, further curriculum evidence can be examined, such as school documents, textbooks, educational manuals and magazines, student and teacher notebooks. To acknowledge and to make a historical observation of these materials implies confronting the intended and actual purposes of a school discipline, which involves knowing how the prescribed contents were actually appropriated by the students, and which methods favored the expected learning.

Additionally, knowing the practices of appropriation allows us to understand an essential aspect of the curriculum beyond the program prescriptions as well as the meanings and intelligibilities given to knowledge by teachers and students, which are the main agents of the school culture.

In this viewpoint magnification, the school curriculum from the perspective of cultural history presents itself as a space for disputes of interests, domination, and control. To problematize such clashes is the main purpose of the curriculum history that we propose to bring to discussion. By placing the of the curriculum under the viewpoint of cultural history, this article aims to analyze power relations and disputes involved in Parana's primary school arithmetic, in an emblematic moment of the history of Brazilian primary school, namely the threshold of the twentieth century. 


\section{PRIMARY INSTRUCTION IN THE BEGINNING OF THE $20^{\text {TH }}$ CENTURY IN THE STATE OF PARANÁ}

The institutionalization of a new school modality was one of the faces of the republican project for society modernization. Considered an excellence model of Brazilian primary's schools, the school group model, initially created in São Paulo in 1893 (SOUZA, 1998), was later disseminated to other Brazilian states. In the state of Paraná, the first school group was stablished in Curitiba in 1903: the Xavier da Silva School Group (BENCOSTTA, 2001).

Conceived in a more rationalized and standardized way, the school groups were constituted as "temples of civilization", aimed at consolidating the republican yearnings for progress and social reform. The legitimation of the new school form, organized in accordance with students' progress, was anchored in conceptions considered to be modern and rational, but conflicting with others in vogue at the time (SOUZA, 1998).

Bencostta (2005) comments on other news that integrated the reality of this primary school model:

The furniture that replaced the torturous backless benches; the blackboard; school supplies linked to the new method that would mark the history of Brazilian primary education - the intuitive method or lessons of things - which predicted the use of maps, cabinets, laboratories, globes, Parker's figures and frames, among others, in order to facilitate the development of students' sensory apprehension faculties; the instrumentalization of didactic readings, let it be said in passing, teeming with a language that, at all times, sought to exalt the republican pride (BENCOSTTA, 2005, p. 71).

In those times (first decades of the twentieth century) of the establishment of the first school groups in the state, the school knowledge distributed in series was taught starting from the definition of concepts, from general to particular, as a science ready to be learned, started from abstract to concrete. Mathematics was present in the school program with the Arithmetic 
discipline, aimed at the development of mental faculties such as attention, imagination, memory, perception that favored the memorization of times tables, formulas, rules to learn the operations, relating the rational to the truth, and how to use mental calculation accurately and quickly after grasping the four operations conventional mechanisms.

In Paraná, the situation of the primary schools was precarious, as the reports of the beginning of the century point out. "In the capital we already have three half groups, each with two schools of different series or grades: Tiradentes School, Oliveira Bello School and Carvalho School. For now, there is a complete group under construction: the Xavier da Silva School Group" (PARANÁ, 1903, p. 8).

In the report presented to the Secretary of Public Instruction on December $31^{\text {st }}$ 1914, the Director of Public Education of the State of Paraná, Dr. Francisco Ribeiro de Azevedo Macedo, informs about what had been accomplished in 1914, regarding the reorganization of state public schools: "I have reunited schools together by systematically dividing and assigning tasks, by series, between the respecting teachers and entrusting one of them with the role of director: so I formed what, in the absence of a better name, we call school groups and semigroups" (PARANÁ, 1914, p. 3).

The director reports that these schools are not organized like the São Paulo state school groups that have special sections for boys and girls. In fact, in the buildings where the first school groups of São Paulo were installed, there were separate spaces for girls and boys beginning in the entrance, such as classrooms, playgrounds, and so on.

In the case of Paraná, the first buildings for the groups were equipped with large halls, for the installation of the four grades, one for each teacher in charge; or in schools that had two classrooms, the semigroups, in which each teacher attended two grades (BENCOSTTA, 2001).

Among the innovations introduced in the programs, among others, it is 
possible to highlight: the systematization of things, proper exercises for senses culture and spirit faculties, exercises for will and character formation, fundamental notions and practices of Moral, Agronomy, Hygiene, Private Economics, and Politics. Regarding materials, the Director notes that schools in São Paulo are endowed with rich technical materials, imported from Europe and North America, while in Paraná, schools have modest materials, comprehending the most necessary, being supplied by teachers' goodwill and skills.

In Curitiba, it was noticeable that not all the first school groups occupied prominent places in the urban scene. Several of them did not have buildings in monumental proportions that deserved, from republican rhetoric, laudatory adjectives, such as: temples or instructions palaces. The functional spaces that the modern pedagogy required, such as a director's office, library, amphitheater, laboratories, secretariat, workshops, courtyards, etc., were also disregarded. The only exceptions in this matter were the school groups Dr. Xavier da Silva and D. Pedro II (BENCOSTTA, 2001, p. 136).

The search for modernization of the public primary school was one of the aspirations of the intellectuals that formed the "Association of the Public Teachers Guild of Paraná", an entity run by teachers, mostly of the main secondary schools of the capital, the Gymnasium and the Normal School. One of the association's activities was the publication of the periodic magazine A Escola (The School), subsidized by the state government and which, since its first edition, in February 1906, published critical news and articles about the state primary school ${ }^{3}$.

Among the most frequent contributors to the magazine, Marach (2007, p. 12) cites: "Cônego Braga, Claudino dos Santos, Dario Vellozo, Ermelino de Leão, Euzébio Motta, Azevedo de Macedo, Sebastião Paraná, Lourenço and Veríssimo de Souza”.

3 Between 1906 and 1910, 25 issues were published. For more details on the journal's publications see: Marach (2007). 
Moved by their youthful impetus, the participants engaged in heated debates on the pages of several newspapers in the capital, without fear of passionate militancy, creating magazines, cultural circles, congregations and institutions such as the University of Paraná itself (MARACH, 2007, p. 13).

In the author's words, it was part of the local literate elite committed to rethinking society and education, understood as the key "for the moral, intellectual and material progress of the population” (MARACH, 2007, p. 22).

In the group characterized as "educationalist"4, there was the name of Dario Vellozo, a professor who teached in Gymnasium level and at the Curitiba's Normal School, an intellectual who was opposed to Catholic ideas and ecclesiastical leaders, and who took over the magazine direction after the first six editions run by Sebastião Paraná (MARACH, 2007).

Inaugurating the $A$ Escola magazine (1906, n.1, p.1), Sebastião Paraná5, laureate geographer and state historian, lens of the Gymnasium and the Normal School of Curitiba, states that, in the republican regime, "instruction is imposed and calls for an immediate solution" (A ESCOLA, 1906, n.1, p. 1). For the distinguished professor and magazine editor, a republican regime could not neglect the education of the people, since "ignorance" and "republic" repelled each other, and a solid instruction required a modern pedagogy. He considered that the primary school, besides taking care of the formation of the character of the child, while developing his reasoning should not pay attention about the memory, but warm the heart and the spirit of the child with the reality of the country, leading him to an exultation with the triumphs and achievements of the homeland and to mourn its disasters. With this founding message, Sebastião

4 Regarding this characterization, Marach (2007) justifies: "the group mentioned was characterized as an educationalist because its own members used this word as a way of referring to those who thought about Brazilian education as a social issue” (p. 13).

5 Sebastião Paraná de Sá Sotto Maior, born in Curitiba, Bachelor of Law and Social Sciences from the Rio de Janeiro School of Law, full professor of General and Brazilian Geography at the Paranaense Gymnasium and Curitiba's Normal School. Sebastião Paraná was author of numerous books such as: History of Paraná and Brazil and Paraná, a work that has reached twenty-two editions. 
Paraná called on teachers, readers of the magazine, to fight with him in defense of a modern school.

Between 1906 and 1910, the journal constituted a space for reflection (and contestation) of local educational issues, in defense of a laic (secular) and free education, as an expression of a practice of equality and freedom. Thus, like the official speeches inscribed in the examined documents, the ones issued by the magazine bring delineations about the purposes of the elementary knowledge to be offered to the population.

In addition to publicizing positions of renowned educators about local instruction and education, the magazine published reports from primary teachers that enlightened what was modern in the didactic-pedagogical organization of school groups and how appropriate the new teaching methods were.

A critique of the mathematical unpreparedness of the Brazilian population, in the first decades of the twentieth century, is addressed to the: uselessness of much of what appears in the school program, the way the teacher conducts the teaching of this discipline in primary school, utilitarian spirit attributed to mathematical instruction in the early twentieth century.

Bonfim (1917), criticizing the rigorous encyclopedic programs in place, the inadequate methods of teaching arithmetic, as well as the narrow and immediate utilitarianism witnessed in official programs and textbooks highlighted the failure of this discipline.

Reduced to a minimum, this preparation constitutes the elementary instruction, which in the initial series is not even a general preparation, but an initiation into the general preparation. Under these conditions - thus reduced, primary instruction must be strictly educational in order to be effectively useful (BONFIM, 1917, p. 105).

In primary school arithmetic, in addition to the fundamental operations 
and decimal metric system, square root and cubic root were included, as well as exchange rates calculations, among other topics such as periodic tithes. Such topics did not meet the students' daily's life needs and were pointed by Bonfim (1917) as responsible for the observed high failure rates. The challenge, posed to the primary education of that epoch, was to overcome the offer of rhetorical knowledge, which was distant from life and understood as a simple rudiment that was not useful to the citizen's life.

Traces of this expected pedagogical modernity were part of the "Regulation of the Public Instruction of the State of Paraná" of 1901 which stated, for example, that "it would be up to the teacher to give teaching the essentially practical character, considering the applications to the needs of life and the direct utility" (PARANÁ, 1901, p. 101).

The inaugural issue of the magazine $A$ Escola was also the spokesman for this criticism in releasing a teacher's report ${ }^{6}$, sent on December $22^{\text {nd }}, 1905$, to the State Director of Public Instruction, Dr. Arthur Pedreira de Cerqueira. In the document, the teacher reports to the state government how she worked with the program at the school she directed, Tiradentes school, one of the first school groups in the state of Paraná. Regarding mathematical knowledge, she informed that she followed Antonio Trajano's book Progressive Arithmetic (TRAJANO, 1924) and Olavo Freire's Practical Geometry (FREIRE, 1907), two books that were used for many years in elementary schools in many Brazilian states. While teaching to students with learning difficulties or more advanced students, she reported to use the mixed mode on Saturdays, where more advanced students helped, in other to recap the discipline subjects.

Regarding the teaching methods the teacher informs:

Applying sometimes the inductive or analytical method and sometimes the deductive or synthetic method, I always try to make the

\footnotetext{
${ }^{6}$ D. Júlia Vanderley Pietrich, teacher and later director of Tiradentes School, one of the first
} school groups created in Curitiba, conducted the first high school chair for females. 
explanations given intuitive and clear, so that the students can thus understand, assimilate and retain the taught lesson. For classes where students have more learning issues, the intuitive method is always of great advantage. The lesson from the parts to the whole, from the simple to the compound, must be based on known and concrete principles and must completely abandon all systems based on abstract principles. I manifestly ostensibly against the teaching taught exclusively by memory in prejudice of other faculties of the intelligence which, without exercise, will inevitably be atrophied. [...] "To know by heart is to not know," as the eminent Montaigne rightly said, and so thinking, I always try to give my students true and solid instruction, bringing school life as close as possible to real life (A ESCOLA, Anno 1, n. 1, 1906, p. 14).

The teacher's reports, published in the referred magazine of Paraná's state, point out characteristics of modern teaching practices of primary school arithmetic, signaling ruptures and transformations that the primary school impressed in its purposes to instruct and educate citizens. 


\section{ARITHMETIC PURPOSES FOR PRIMARY SCHOOLS}

At the beginning of the century, there was a clash among anti-clerical 7 intellectuals about the primary school in the state, witnessed by the magazine $A$ Escola. In the discussions, there were references about the purposes of a modern primary school, outlined by several educators, such as Dario Vellozo, the distinguished normal School teacher. He speaks about the need to direct instruction with theory and practice while defending attributes of the Enlightenment such as reason, science, and freedom of conscience, while guaranteeing the intellectual autonomy of individuals. "This emancipation by reason, freeing itself from oppression (Catholic Church), made him to elaborate a proposal that allied science and moral with civism, thus forming, the tripod of progressivism education" (ANDRADE, 2007, p. 197).

He considered that the state, by providing and facilitating instruction and education, allowed the individual to become a "conscious cell in collectivity", armed him for the struggle for life, and the return would be the progress of the state.

The instruction given to children and youth does not satisfy, cannot persist without serious prejudice to our patricians. It is superficial, rhetorical, exhausting, almost useless. It is not enough to teach reading, writing and counting; It is not enough to drag the youth into the bitterness of the most complicated theories, under the alluvium of overwhelming details; It is not enough to INSTRUCT; It is necessary to EDUCATE: to arm the individual for the fight and for victory. The instruction is the medium, education is the END: the TERM (VELLOZO, 1907, p. 107, emphasis given by original author).

In this article, Vellozo appealed for the school to get as close as possible to its own living conditions and stressed out the need to better distribute the discipline subjects, rather than reformulating programs and regulations.

7 By debating religious doctrines and questioning how institutions, the anti-clericalism involved young students that were attending the Ginásio Paranaense and Escola Normal de Curitiba (ANDRADE, 2007). For more details on this movement, see Balhana (1980). 
The reform of the regulations, the clamor against the methods is insufficient. It would be better to replace the programs, to redistribute the disciplines, selected with sobriety and criteria. However superior the teaching methods may be, the teacher is adstricted to the archaic and tremendous, fussy, complex and unassimilable programs. [...] The question is no longer just how they teach, but mainly what they teach (VELLOZO, 1907, p. 111, emphasis given by original author).

By addressing the criticism of programs and methods, as underlined, Vellozo (1907) refers to the "Internal Regulation of Paraná's State Public Schools" (PARANÁ, 1903), a decree that prescribed rules most of which were pedagogical-administrative recommendations. The list of subjects and programs remained unchanged compared to those set out in the 1901 regulation, however, the "Annex 4" included a list of books nominated by the congregation of teachers of the Gymnasium and Normal School, as a suggestion for adoption at the state primary schools. For the arithmetic discipline, Antonio Trajano's ${ }^{8}$ books of Elementary Arithmetic and Progressive Arithmetic were suggested. It is observed that the second indicated title is the same cited in the report of the teacher Julia Vanderley, published in the magazine A Escola as previously mentioned.

In an article published in March, 1908, the third year of the $A$ Escola magazine, Vellozo presents a proposal for Modern School, claiming that it is necessary to defend a work of hands and brain, since the early school years, "neither only theorists, nor only routine" [...] "The current school leads to bureaucracy; the Modern School, giving utilitarian teachings, indicates to the student the agriculture, the commerce, the arts, and industries" (A ESCOLA, Year 3, n. 1, 1908, p. 8).

In the following year, in the article "Subsídios Pedagógicos" "Pedagogical Subsidies"), Vellozo (1909) again criticizes the current school and its teaching. By bringing ideas from thinkers such as Chasteau, Compayré, Le Bom, Demolins, Spencer, among others, who he said contributed to illuminating

\footnotetext{
${ }^{8}$ For further details on Trajano's works it is suggested to see Oliveira (2013).
} 
the subject, he highlights the school's responsibility for conscious and productive work. "The production grows with work; conscious and productive work is learned in schools; not in poor rudimentary and primitive schools, but in schools of modern, utilitarian and technical organization" (A ESCOLA, Anno 4, n. 2 e 3, 1909, p. 49).

By defending the idea that the theory taught at school needed to be used in immediate practical applications, Vellozo asserts that neither the state nor the country took care of adapting the public education to the needs of its economic and civic functions. The programs should follow in a logical unfolding, without fractionation, from primary schools to secondary courses.

The Modern School, conceived by Vellozo as the soul of a Civic Brazil, should provide more than the theory of moral principles or the practical knowledge of duties, but also preparing the child to perform honestly all off life obligations. For him, the issue was not only of pedagogical order. It was a matter of social and civic aspects, considering that intuitive utility was not the single factor in civility.

After five years of its creation, in the issue of n. 7-12, 1910, the extinction of the $A$ Escola magazine is announced (p. 349). A note on page 176 of issues $n$. 1 to 3 draws the reader's attention:

Now that, in the most civilized centers in Brazil, the creation of schools in the rationalist molds of de Ferrer is being considered, the reminder that this idea has already existed in Paraná since 1906, and that the outstanding educator Dr. Dario Vellozo, lens of the Gymnasium's History, laid the foundations of its Modern School, an admirable teaching institute that earned the approval of consecrated masters of old Europe (A ESCOLA, 1910, p. 176).

Curiously, this note is published in the same issue in which the magazine publishes two articles about the Spanish educator, Francesc Ferrer i 
Guardia 9 and a poetry entitled "Ferrer's shooting. (Injustice)".

The educator's proposal for a Modern School "combined science and morals with civics, thus forming the tripod of the Enlightenment education" (ANDRADE, 2007, p. 197). When contemplating culture and work with a view towards progressive and modern education, Vellozo defended a new pedagogy, unimpeded, laic and cost free, opposing, in his line of thought, to a clerical past.

The strong criticisms that the magazine $A$ Escola issued against the state primary school, intensified by Vellozo since 1907, possibly led to the suspension of the journal in 1910 and also to the suspension of Vellozo, by act of the State's President Francisco Xavier da Silva Group at March $9^{\text {th }}$ of 1909 , for three and a half months, of his duties in the chair of the Gymnasium Paranaense and Escola Normal (ANDRADE, 2007, p. 198).

\begin{abstract}
And Vellozo, in spite of the flagrant refusal of his Study Plan and Program - modern school - by the legislative congress of the state of Paraná, continued to promote the cause of laic education, as he was still optimistic about the implementation of such a teaching establishment and stated that in Paraná's state the modern school would still rise (ANDRADE, 2007, p. 201).
\end{abstract}

Andrade (2007) notes that, in 1914 Vellozo managed to establish, in the city of Rio Negro/PR, the "Brazil-Civic School" along the same lines as the modern school.

In the year prior to the magazine suspension, the government had approved a regulation for primary schools (PARANÁ, 1909), defining a new structure comprising early childhood education (1 year), elementary education (4 years) and supplementary education (2 years). In such regulation, the Article

\footnotetext{
9 The Spanish pedagogue Francesc Ferrer i Guardia was a supporter of the educational ideas of free and libertarian thought of the early twentieth century. He bet on scientific and rational teaching, not subordinated to the imperatives of religion and the state. The Modern School created by him in Barcelona was closed but other rationalist schools sprang up in other countries. See CARBONEL, J; SEBARROJA, J. C. [et al.]. Pedagogies of the twentieth century. Porto Alegre: Artmed, 2003.
} 
74 informed about the intuitive and practical character to be given to teaching, in accordance with the programs and methods, now authorized by the Higher Board of Education, the body created to decide on pedagogical subjects of primary schools, such as the definition of methods, and the determination of textbooks to be adopted in the disciplines.

According to the new regulation, it would be up to the teacher to develop children's intelligence through the teaching of things, as well as to systematize their spontaneous inclinations to concrete facts. As indicated by the newly created council, Antonio Trajano's books, which had been adopted since 1903 , for the teaching of arithmetic, would be replaced by Souza Lobo's books ${ }^{10}$.

Analysis conducted by Valente (2015) show that textbooks widely used in Brazilian primary schools followed different logics in the proposition of programmatic subjects: one that considered mathematical knowledge as elements and another that considered them as rudiments. The first, heiress of the scientific tradition, whose rationality excels in presenting the knowledge, from the simplest to the most complex, where the simple is the initial content, the complex that comes next and which encompasses several simple elements. The structure that internally organizes the program comprises a logic of elements, as a rationalist logic that considers the progress of knowledge and which aims to instruct from what is considered to be prerequisite an elementary knowledge that is at the base and further advances towards higher levels of knowledge.

Another logic, the logic of rudiments, which is a pedagogical tradition that organizes content from easy to difficult, signs for an educational objective of knowledge, that is useful for practical life, considers the interests of those who learn. According to Valente (2015), the idea of rudiments is closer to practical purposes, but more distant from academic purposes, farther from

\footnotetext{
1o Valente (2015) comments that Souza Lobo's Primeira Arithmética para Meninos (First Arithmetic for Boys) is "an emblematic text to refer to the synthetic method for the teaching of Arithmetic” (p.200), and Antonio Trajano's Arithmética Primária (Primary Arithmetic) presents marks of both analytical method as well as the synthetic method.
} 
science which usually is more concerned about educating than just instructing.

In face of such clash of methods, which direction has arithmetic taken in the curriculum of the Paranás primary schools?

In 1921, a new magazine, also named $A$ Escola provides detailed guidance to teachers on how to work with the intuitive method and use Parker's Letters ${ }^{11}$, a popular material for school groups in São Paulo and whose use was widespread in school groups across the country. It was a time when the organization of primary education in Paraná gained new contours with the circulation of the ideas of the New School movement, in which educational debates focused attention on the method and modernization of primary schools. The official program for the school groups since the creation of this modality of education, which was under construction, was finally published in detail as the Model School Group Program (PARANÁ, 1916), an initiative that led the state to new enterprises aimed at modernization of primary school. Among these initiatives, there was the hiring of São Paulo educator César Prieto Martinez, invited in the early 1920 s to assume as Director of Public Instruction of Paraná.

With the program officialization, written especially for the school groups, the new programmatic organization assumed the synthetic method instead of the analytical one, with less watertight and more globalized activities, with disciplines sympathizing with the reach of the practical spirit, that was the great purpose proposed for primary schools at that period.

In arithmetic, as in other disciplines of primary school, the intuitive method that Pestalozzi said spoke to the student's brain and heart, reigned supreme in the "Lições de Coisas"12 ("Lessons of Things") as well as in the Parker's Letters, setting up a practical, easily taught arithmetic for children to learn.

With the new pedagogical organization of the curriculum, the

\footnotetext{
${ }^{11}$ In Paraná this material was present in primary schools, from 1917 to 1950. See Portela (2014).

${ }_{12}$ About the "Lições de Coisas" ("Lessons of Things") see Valdemarin (2004).
} 
knowledge to teach arithmetic became more complex, also requiring a restructuring of the teacher education curriculum.

Faced with the need for a new understanding about the practical, and about the transition from the "simple to the complex", the teacher training courses left aside "mathematics for life" to incorporate knowledge to teach "the mathematics of life". To expand the pedagogical space in the curriculum, Martinez added his contribution to the formation by adding disciplines of professional culture ${ }^{13}$.

Other actions, equally promising for the modernization of primary education, were Martinez's initiatives aimed at the model school which was attached to the Secondary Normal School, after the reform of Lysimaco Ferreira da Costa ${ }^{14}$, such as the preparation of teachers for the use of the Parker's Letters and intuitive method in Arithmetic's teaching.

On how to modernize the teaching of Arithmetic, Martinez publishes an article in the magazine A Escola (1921), which was a periodic considered as an instrument aimed at professional development and a vehicle for the dissemination of knowledge for the modernization of primary schools in the state.

In the article entitled Arithmetic (A ESCOLA, 1921), author P. M.15 extols the value of this discipline which he considers indispensable for practical life, whatever the conditions, stating that when it comes to commerce, this discipline is the soul. To the teachers, he recommends that the teaching of the discipline should be "as practical as possible, intuitive, rational and yet graduated, aiming not at the accumulation of the contents, but at the

\footnotetext{
13 About transformations occurred in 1920 decade in the Normal School of Paraná see Abreu (2007); Moreno (2007); França (2015).

14 Abreu (2007) comments about the scarce reference to Martinez as the author of the education reform in Paraná, in the 1920s: "only the reform of the Normal School undertaken by Lysimaco Ferreira da Costa was regulated and officially recognized by the government" (p. 102).

15 P.M. stands for the initials used by Revista A Escola (A ESCOLA, 1921) for the author of the article César Prieto Martinez.
} 
effectiveness of what is taught" ((A ESCOLA, 1921, p. 19). He recommends that in order to prevent the student from getting used to memorizing compendiums and entrusting memory with what is unique to reasoning, teaching should be intuitive. Regarding the analytical method, the author observes:

\footnotetext{
Recently adopted and therefore barely known or even unknown, among us, by some educators, a huge campaign has raised against him, especially about certain subjects, such as Reading and Arithmetic; but, thanks to the results presented, he goes little by little, introducing himself in our primary education, which already has many School Groups and some Isolated Schools where he is exclusively adopted (A ESCOLA, 1921, p. 19).
}

The author also stated that in order to achieve a practical and useful end, the discipline needs to be worked with intelligence, not mechanically, in which the student does not have to explain the process and the means available to find the answer to the question. It must be a teaching that allows the student to get used to "reflect, deduce, reason on an issue, examine data and establish relationships, and examine the nature of the operations" (A ESCOLA, 1921, p. 19).

Beyond the renewal of teaching methods, the dynamization of the practical spirit reassures the good use of the intuitive method in the graduate school, by prioritizing the effectiveness of what would be taught and not the accumulation of contents.

\section{FINAL CONSIDERATIONS}

Three fundamental premises, problematized under the viewpoint of cultural history, by curriculum theorists, contributed to the construction of this narrative that sought to analyze power relations and disputes involved in education, especially in the arithmetic of Paranás primary school, in an 
emblematic moment of the history of Brazilian primary school which was a threshold of the twentieth century.

The first premise is that the curriculum is not something fixed since it is in constant flow and transformation. However, by including permanencies and ruptures it should not be interpreted as an evolutionary process, in continuous improvement. This is what can be noted in the arithmetic at the beginning of the century, with the protagonism of the intuitive method, as pointed out by the reports of the teacher Julia Vanderlei published by the magazine $A$ Escola, and later, in the early 1920s, by the interventions made by Martinez in Paraná's primary schools, guiding teachers on how to give a practical sense to the arithmetic discipline in order for it to achieve its real purposes.

The second premise is that addressing the curriculum historically does not mean turning to the past in order to know how school knowledge was organized in comparison to the current teaching. As indicated by the magazine A Escola, between 1906 and 1910, with the manifestations of Dario Vellozo and other intellectuals who defended the modern school, the important thing is to go back to the past to understand the reasons why some knowledge was taught and not others.

The debates about the modernization of primary school, which were fierce in Paraná on the threshold of the twentieth century, are in line with the third premise, which considers the curriculum not as a peaceful field, but as a process consisting of struggles and conflicts, full of traditions, beliefs, expectations and social visions.

The clashes in the beginning of the century between Paranás intellectuals and conservative forces linked to the Catholic Church, and Martinez's interventions to modernize Paraná's primary education, attest that in different times and spaces, particularly in times of occupation of the Paraná lands, whether in the most modest schools in the interior of the state, or in modern school groups located in more urbanized regions, the teaching of arithmetic has fomented close relationships between school culture and other 
cultures such as religious and economic, helping directly or indirectly to maintain the practical dimension of a knowledge that was object of power disputes in different historical periods.

The history of the Mathematics curriculum, related to any level and modality of education, therefore, is linked not only to methods and content, but also to educational reforms on whose basis includes purposes, intentionalities, choices that creates access possibilities to a systematized knowledge for the population.

In Paraná's State, the consolidation of the model of graduated and serial school, spread from São Paulo's State, was a slow and not peaceful process since the creation, in 1903, of the first school group in the state. The magazine $A$ Escola, a division of the "Association of the Public Teachers Guild of Paraná" was a stage, in the period between 1906 and 1910), of an intense debate about the modernity of primary school in the state and the dilemmas that emerged around scientific education vs religious education, general culture vs professional culture, and instruction $v s$ education.

By criticizing the weaknesses of the teaching programs and the precarious structure of the schools, the magazine also brought to the public reports of successful didactic experiences of the intuitive method, in addition to a bold proposal for a modern school, in which the subjects were thought in terms of a libertarian pedagogy. which rejected the religious morality prevalent in society.

Another magazine, directed by Dr. Candido Natividade, published in the $1^{\text {st }}$ edition on March $25^{\text {th }}, 1921$, also a part of the Guild of Public Teachers of Paraná, which despite using the same name does not appears to be a continuation of the previous one - as articles in the two initial editions indicate - sought to provide an answer to an old question that, at the dawn of the 2oth century, confronted the Paraná's intellectuals: what purposes should Arithmetic achieve in times of pedagogical modernity brought by the serial and graduated school? 
With a focus on the modernization of education and the achievement of real purposes for the primary school, especially for the teaching of arithmetic, César Prieto Martinez, the head of the state's Board of Public Instruction at the time, demonstrated in the early 1920 decade that the success of a scholar curriculum is not made without an efficient investment in the teacher, mainly intervening in its formation and following the way it mobilizes the necessary knowledge for the implementation of the new teaching programs.

His initiatives marked educational actions regarding the implementation of a detailed program for each grade of primary education, incremented by the offer of new subjects thanks to the Reform of the Normal State School, coordinated by Lysimaco Ferreira da Costa, and opened space in the curriculum for to valorization of the professional culture of the primary school teacher, by resizing their professional formation in order to guarantee the degree of excellence of the Arithmetic in the first school years.

Beyond the pedagogical questions, his actions referred to the power relations that involve the curriculum. The curriculum when viewed historically is not only simple data. It is more likely to be a black box that needs opening. Such condition considers the unveiling of behind-the-scenes logic present in printed materials impregnated of subjectivity of individuals. Apart from official documents, bearers of the so valued scientific logic, the real reasons of a curricular proposal, their genuine objectives are in a special space of the school, the space of the school culture, place where new purposes are incorporated to the contents and teaching methods. 


\section{REFERENCES}

A ESCOLA. Revista do Grêmio dos Professores Públicos do Estado do Paraná. Coritiba/Pr: Anno 1, n. 1, 1906.

A ESCOLA. Revista do Grêmio dos Professores Públicos do Estado do Paraná. Coritiba/Pr: Anno 3, n. 8 e 9, 1907.

A ESCOLA. Revista do Grêmio dos Professores Públicos do Estado do Paraná. Coritiba/Pr: Anno 3, n. 1, 1908.

A ESCOLA. Revista do Grêmio dos Professores Públicos do Estado do Paraná. Coritiba/Pr: Anno 4, n. 1, 1909, p.49.

A ESCOLA. Revista do Grêmio dos Professores Públicos do Estado do Paraná. Coritiba/Pr: Anno 4, n. 2 e 3, 1909, p. 46-62.

A ESCOLA. Revista do Grêmio dos Professores Públicos do Estado do Paraná. Coritiba/Pr: Anno V, n. 1 a 3, 1910, p. 176-177.

A ESCOLA. Revista do Grêmio dos Professores Públicos do Estado do Paraná. Coritiba/Pr: Anno V, n. 7 a 12, 1910.

A ESCOLA. Revista do Grêmio dos Professores Públicos do Estado do Paraná. Coritiba/Pr: Anno 1, n. 2, 1921.

ABREU, Geysa Spitz Alcoforado de. A trajetória de Lysimaco Ferreira da Costa: educador, reformador e político no cenário da educação brasileira (Final do século XIX e primeiras décadas do século XX). 222 f. Tese (Doutorado em Educação) - Programa de Pós Graduação em Educação, Pontifícia Universidade Católica de São Paulo/SP, São Paulo, 2007.

ANDRADE, Maria Lúcia de. Dario Vellozo e a escola moderna: a renovação do pensamento educacional no Paraná (1906-1918). In: VIEIRA, Carlos Eduardo (org.). Intelectuais, educação e modernidade no Paraná (1886-1964). Curitiba: Ed. UFPR, 2007. p. 191-217.

BALHANA, Carlos Alberto de Freitas. Idéias em confronto. 177 f. Dissertação (Mestrado em História do Brasil). Programa de Pós Graduação em História, Universidade Federal do Paraná, Curitiba, 1980.

BENCOSTTA, Marcus Levy Albino. Arquitetura e espaço escolar: reflexões acerca do processo de implantação dos primeiros grupos escolares de Curitiba (1903-1928). Educar, Curitiba, Editora da UFPR, n. 18, p. 103-141. 2001. 
BENCOSTTA, Marcus Levy Albino. Grupos escolares no Brasil: um novo modelo de escola primária. In: STEPHANOU, Maria; BASTOS, Maria Helena Camara (org.). Histórias e memórias da educação no Brasil. v. III - Século XX. Petrópolis/RJ: Vozes, p. 68-76, 2005.

BONFIM, Manoel. Lições de Pedagogia. 2. ed. Rio de Janeiro: Francisco Alves, 1917.

CHERVEL, André. História das disciplinas escolares: reflexões sobre um campo de pesquisa. Teoria \& Educação, Porto Alegre, n. 2, p. 177-229, 1990.

FRANÇA, Iara da Silva. Do Ginásio para as Escolas Normais: as mudanças na formação matemática de professores do Paraná (1920-1936). 287 f. Tese (Doutorado em Educação). Programa de Pós Graduação em Educação, Pontifícia Universidade Católica do Paraná, Curitiba, 2015.

FREIRE, Olavo. Geometria prática. Rio de Janeiro: Livraria Francisco Alves, 1907.

GOODSON, Ivor F. Currículo: teoria e história. 13. ed. Petrópolis/RJ: Vozes, 2012.

JULIA, Dominique. A cultura escolar como objeto histórico. Revista Brasileira de História da Educação, n. 1, p. 10-43, jan./jun. 2001.

MARACH, Caroline Baron. Inquietações modernas: discurso educacional e civilizacional no periódico A Escola (1906-1910). 115 f. Dissertação (Mestrado em Educação). Programa de Pós-Graduação em Educação, Universidade Federal do Paraná, Curitiba, 2007.

MORENO, Jean Carlos. Intelectuais na década de 1920: César Prieto Martinez e Lysimaco Ferreira da Costa à frente da instrução pública no Paraná. In: VIEIRA, Carlos Eduardo (org.). Intelectuais, educação e modernidade no Paraná (1886-1964). Curitiba: Ed. UFPR, p. 41-64, 2007.

NÓVOA, António. Histoire \& Comparaison (Essais sur l’Éducation). Lisboa: Educa, p. 51-84, 1998.

OLIVEIRA, Marcus Aldenísson. Antonio Bandeira Trajano e o método intuitivo para o ensino de Arithmética (1879-1954). $142 \mathrm{f}$. Dissertação (Mestrado em Educação). Programa de Pós-Graduação em Educação, Universidade Tiradentes. Aracaju/SE, 2013. Disponível em: http://repositório.ufsc.br/handle/123456789/105123. Acesso em: 29-mai2020. 
PARANÁ. Regimento Interno das Escolas Públicas do Estado do Paraná. $1903 . \quad$ Disponível em: https://repositorio.ufsc.br/xmlui/handle/123456789/134515. Acesso em: 29Mai-2020.

PARANÁ. Regulamento da Instrução Pública do Estado do Paraná. $1901 . \quad$ Disponível em: https://repositorio.ufsc.br/xmlui/handle/123456789/123700. Acesso em: 29Mai-2020.

PARANÁ. Relatório apresentado ao Secretário do Interior, Justiça e Instrucção Publica pelo Dr. Victor Ferreira do Amaral. 1903, 19p. Disponível em: http://repositorio.ufsc.br/xmlui/handle/123456789/99762. Acesso em: 29-Mai-2020.

PARANÁ. Regulamento Orgânico do Estado do Paraná. 1909. Disponível em: https://repositorio.ufsc.br/xmlui/andle/123456789/99855. Acesso em: 29Mai-2020.

PARANÁ. Relatório do Diretor Geral da Instrução Pública. 1914. Disponível em: https://repositorio.ufsc.br/xmlui/handle/123456789/100101. Acesso em: 29-Mai-2020.

PARANÁ. Programa de Ensino e sua execução nos institutos públicos do curso primário. Curitiba, 2016. Disponível em: https://repositorio.ufsc.br/xmlui/handle/123456789/123959. Acesso em: Acesso em: 29-Mai-2020

PORTELA, Mariliza Simonete. As Cartas de Parker na matemática da escola primária paranaense na primeira metade do século $\mathrm{XX}$ : circulação e apropriação de um dispositivo didático pedagógico. 189 f. Tese (Doutorado em Educação). Programa de Pós Graduação em Educação, Pontifícia Universidade Católica do Paraná-PR, Curitiba, 2014.

SEBARROJA, Jaume Carbonell (org.). MONTESSORI, Maria. GUARDIA, Francesc Ferrer i. DEWEY, John. RÍOS, Francisco Giner de Los. FREINET, Célestin. NEIL, Alexander Sutherland. MAKARENKO, Anton Semyonovich. PIAGET, Jean. MILANI, Lorenzo. FREIRE, Paulo. STENHOUSE, Lawrence. Pedagogias do século XX. Porto Alegre: Artmed, 2003.

SOUZA, Gizele de. Instrução, o talher para o banquete da civilização: cultura escolar dos jardins de infância e grupos escolares no Paraná, 1900-1929. 317 f. Tese (Doutorado em História, Política, Sociedade). Programa de Estudos Pós Graduados em Educação, Pontifícia Universidade Católica de São Paulo-SP, 
São Paulo, 2004.

SOUZA, Rosa Fátima de. Templos de civilização: a implantação da escola graduada no Estado de São Paulo (1890-1910). São Paulo: Editora da Unesp, 1998.

TRAJANO, Antonio. Arithmética Progressiva: curso superior, theórico e prático. 32. ed. Rio de Janeiro: Livraria Francisco Alves, 1924.

VALDEMARIN, Vera Teresa. Estudando as Lições de Coisas: análise dos fundamentos filosóficos do método de ensino intuitivo. Campinas, SP: Autores Associados, 2004.

VALENTE, Wagner Rodrigues. Como ensinar matemática no Curso Primário? Uma questão de conteúdos e métodos. Perspectivas da Educação Matemática, UFMS, v. 8, n. 17, p. 196-207, 2015.

VELLOZO, Dario. Subsídios pedagógicos: da Instrucção Popular. PARANÁ. Revista A Escola, Órgão do Grêmio dos Professores Públicos do Paraná, anno 2, n. 8 e 9, p. 110, 1907.

VELlozO, Dario. Escola Moderna. PARANÁ. Revista A Escola, Órgão do Grêmio dos Professores Públicos do Paraná, anno 3, n. 1, p. 8, 1908.

VELLOZO, Dario. Subsídios Pedagógicos. Da instrucção popular hodierna. Revista A Escola, Órgão do Grêmio dos Professores Públicos do Paraná, anno 4, n. 2 e 3, p. 46-62, 1909.

VIÑAO, Antonio. A história das disciplinas escolares. Revista Brasileira de História da Educação, SBHE, Campinas, Autores Associados, n. 18, p. 174$215,2008$. 
NEUZA BERTONI PINTO holds a PhD in Education from the University of São Paulo. She is a retired Professor from the Pontifical Catholic University of Paraná, where she worked as a Professor in the courses of Pedagogy, Mathematics Licentiate, Master and Doctorate in Education, between 2000 and 2016. Currently she is a Teacher Collaborator Post-Graduate Program in Education in Science and Mathematics - PPGECEM - REAMEC - UFMT, Vice President and Researcher at Ghemat Brasil and Researcher at Ghemat Paraná. She conducts research in the area of the History of Mathematical Education, especially related to the training of teachers and specialists in teaching mathematics who teach mathematics in the early school years.

E-mail: neuzabertonip@gmail.com

(b) http://orcid.org/0000-0002-9224-3020

Recebido em: 03 de janeiro de 2020

Aprovado em: 18 de março de 2020

Revista História da Educação - RHE

Associação Sul-Rio-Grandense de Pesquisadores em História da Educação - Asphe

Artigo de acesso aberto distribuído nos termos de licença Creative Commons. 